\title{
UPAYA SWAMEDIKASI DENGAN TANAMAN OBAT PADA KELOMPOK IBU-IBU PKK DI KELURAHAN KALAMPANGAN
}

\author{
Maryani $^{1)}$, Rosdiana ${ }^{2)}$ \\ ${ }^{1)}$ Staf Pengajar Jurusan Perikanan Fakultas Pertanian Universitas Palangka Raya \\ Email : mayamadjid99@yahoo.co.id \\ ${ }^{2)}$ Staf Pengajar Jurusan Kehutanan Fakultas Pertanian Universitas Palangka Raya \\ Email : rosdianamurhaini@ymail.com
}

\begin{abstract}
Abstrak
Pembinaan terhadap ibu-ibu PKK di Kelurahan Kalampangan Kecamatan Sabangau Kota Palangka Raya untuk meningkatkan pengetahuan dalam upaya melakukan swamedikasi dengan tanaman obat adalah dengan menyelenggarakan tiga jenis pelatihan yang berkaitan dengan swamedikasi menggunakan tanaman obat dan melakukan pemantauan terhadap kegiatan yang dilakukan. Manfaat yang diperoleh dari hasil kegiatan adalah meningkatnya keterampilan dan pengetahuan ibu-ibu PKK dalam mengenal jenis tanaman obat, penguasaan teknis pembuatan dua jenis ramuan jamu, yaitu jamu beras kencur, kunyit asam, dan penguasaan terhadap teknis pembuatan kompos organik dengan bahan dari limbah rumah tangga. Selanjutnya dilakukan pula monitoring dan evaluasi terhadap pelatihan yang telah dilakukan dengan kunjungan dan wawancara. Hasil monitoring dan evaluasi yang telah dilakukan menunjukkan bahwa telah terjadi peningkatan konsumsi beras kencur dan kunyit asem dalam keluarga dan dalam kegiatankegiatan di lingkungan warga. Transfer ilmu tentang manfaat jenis-jenis tanaman obat keluarga yang ada di lingkungan sekitar dan pembuatan jamu juga telah terjadi dari ibu-ibu peserta pelatihan kepada warga yang tidak mengikuti pelatihan secara informal. Tanaman obat yang dibagikan kepada peserta pelatihan saat kegiatan pengabdian dilakukan juga masih terpelihara dengan baik di pekarangan rumah. Secara keseluruhan kegiatan pemberdayaan pada kelompok ibu-ibu PKK Kelurahan Kalampangan, Kecamatan Sabangau Kota PaLangka Raya Kalimantan Tengah telah berjalan dengan baik.
\end{abstract}

\section{Kata kunci : swamedikasi, jamu, tanaman obat, beras kencur, kunyit asam}

\section{PENDAHULUAN}

Gelombang "back to nature" oleh sebagian besar masyarakat menciptakan tren global terhadap pangan organik serta obat, vitamin dan suplemen herbal. Perkembangan populasi penduduk dunia yang mencapai 6 milyar menyebabkan kebutuhan bahanbahan diatas melonjak tajam. Indonesia yang dikaruniai wilayah sangat luas dan kekayaan alam berlimpah, merupakan salah satu pusat raksasa (mega center) keanekaragaman hayati yang dimiliki planet ini. Potensi luar biasa ini dapat digunakan sebagai lahan pengembangan industri herbal medicine dan health food untuk kebutuhan dunia.

Saat ini, pemanfaatan bahan baku obat herbal oleh masyarakat mencapai kurang lebih 1000 jenis, dimana 74\% diantaranya merupakan tumbuhan liar yang hidup di hutan. Tingkat pemanfaaatan tumbuhan obat masih jauh dari potensi yang ada di alam. Oleh karena itu dengan meningkatnya kebutuhan bahan bakusimplisia, dan meluasnya permintaan pasar domestik maupun ekspor, akan meningkatkan pemanfaatan tumbuhan obat yang ada di Indonesia. 
Swamedikasi dapat diartikan sebagai upaya untuk mengobati diri sendiri tanpa berkonsultasi dengan dokter (Winkanda, 2013). Upaya swamedikasi ini dapat dilakukan berbekal pengetahuan yang cukup tentang cara mengetahui gejala penyakit dan juga pengetahuan tentang khasiat obat. Salah satu jenis bentuk swamedikasi adalah dengan mengunakan obat tradisional yang umumnya mengandung bahan berkhasiat yang berasal dari jenis tumbuhan (Pusat Studi Biofarmaka, 2003). Dalam upaya menggalakkan kembali penggunaan jamu sebagai warisan nenek moyang yang perlu dilestarikan, maka generasi muda saat ini yang sudah kurang mengenal jamu perlu diedukasi kembali. Tanaman obat sebagai bahan berkhasiat jamu perlu diperkenalkan kembali sehingga masyarakat dapat melakukan swamedikasi dengan tanaman obat dan budi daya tanaman obat akan semakin berkembang sehingga kekayaan hayati kita khususnya tanaman obat dapat terus terpelihara dan tidak menjadi punah.

Kelurahan Kalampangan merupakan daerah subur yang merupakan daerah penghasil sayur-sayuran untuk Kota Palangka Raya, sehingga dilihat dari kesuburan tanah di Kelurahan Kalampangan maka Kelurahan Kalampangan dapat dijadikan sebagai sentra penghasil tanaman obat tradisional selain sebagai sentra penghasil sayur-sayuran.

Tujuan dari pelaksanaan IbM ini adalah melakukan pembinaan terhadap ibuibu PKK di Kelurahan Kalampangan Kecamatan Sabangau Kota Palangka Raya dengan menyelenggarakan tiga jenis pelatihan yang berkaitan dengan swamedikasi menggunakan tanaman obat dan melakukan pemantauan terhadap kegiatan yang dilakukan. Manfaat kegiatan ini adalah dapat meningkatkan keterampilan dan pengetahuan ibu-ibu PKK dalam mengenal jenis tanaman obat, membudidayakannya dalam lahan sempit, serta cara mengolah tanaman obat yang dapat digunakan untuk swamedikasi di keluarga maupun lingkungan sekitarnya.

\section{METODE PELAKSANAAN}

Masyarakat dan kelompok sasaran adalah ibu-ibu PKK dari RT 03 RW III Kelurahan Kalampangan Kecamatan Sabangau Kota Palangka Raya. Pelaksanaan kegiatan dilakukan di Bulan SeptemberOktober 2016 di Kelurahan Kalampangan Kecamatan Sabangau Kota Palangka Raya. Kegiatan dilaksanakan dalam bentuk pelatihan dan pendampingan dengan beberapa kali tatap muka. Sebagai langkah awal dalam pelaksanaan program IbM ini maka dilakukan sosialisasi program Ipteks bagi Masyarakat kepada masyarakat Kelurahan Kalampangan Kecamatan Sabangau Kota Palangka Raya. Sosialisasi dilakukan dengan melakukan permohonan izin kepada pihak Kelurahan Kalampangan.

\section{- Pelatihan Pertama Pengenalan} Tanaman Obat.di Lingkungan Sekitar

Peserta dikenalkan dengan berbagai macam tanaman obat, berlatih mengenal ciri morfologi tanaman, dan bagian-bagian tanaman yang berkhasiat sebagai obat, serta berlatih mengenal tanaman obat dan khasiatnya. Untuk menarik peserta pelatihan, selama pelatihan diberikan dalam bentuk game dan kuis. Media: berbagai jenis tanaman obat dalam bentuk segar (dalam pot), materi slide pengenalan tanaman obat, dan pembagian tanaman obat dan media

\section{- Pelatihan Kedua Cara Pemanfaatan Tanaman Obat}

Untuk meningkatkan kecintaan kepada tanaman obat, maka peserta diberikan pelatihan cara meracik tanaman obat menjadi sediaan jamu. Sediaan jamu yang dipraktikkan adalah jamu yang mudah dibuat dan juga umum digunakan untuk meningkatkan kesehatan keluarga, yaitu jamu minuman kunyit asam dan beras kencur. Selain itu, dipraktikkan juga 
pembuatan jamu beras kencur dalam bentuk sediaan minuman instan.

Bahan terdiri dari; 1) Ramuan untuk beras kencur minuman cair; 2) Ramuan untuk kunyit asam.

\section{- Pelatihan Ketiga Pembuatan Kompos}

Keterampilan lain yang menunjang kesuburan tanaman obat di pekarangan adalah pembuatan kompos, maka dilakukan pelatihan pembuatan pupuk kompos yang berasal dari sampah organik. Pelatihan dilakukan secara demonstrasi. Bahan: sampah organik, air bekas cucian beras atau air kelapa, gula merah, dan wadah untuk fermentasi. Cara pembuatan: sampah organik dirajang, kemudian direndam dengan air cucian beras atau air kelapa, kemudian tambahkan gula merah secukupnya lalu dicampurkan hingga merata. Wadah selanjutnya ditutup dan dibiarkan selama 10-14 hari. Setelah tercium bau cuka (kurang lebih 10-14 hari), kompos organik sudah terbentuk, pisahkan kompos cair dan kompos padatnya. Kompos cair dapat disimpan dalam botol untuk sewaktuwaktu diperlukan, dan kompos padatnya dapat dikeringkan dan dikemas dalam plastik. Kompos cair dan kompos padat sudah siap untuk digunakan.

\section{Evaluasi dan Monitoring}

Evaluasi dan monitoring dilakukan secara berkala dengan mendatangi rumah warga ibu-ibu PKK untuk mengetahui sejauh mana pelatihan yang diberikan dapat diimplementasikan. Kriteria tanaman obat yang diberikan masih terpelihara dengan baik di pekarangan rumahnya.

\section{HASIL DAN PEMBAHASAN 1. Pelatihan Pengenalan Tanaman Obat di Lingkungan Sekitar}

Pelatihan pertama yang dilakukan adalah Pelatihan Pengenalan Tanaman Obat Di Lingkungan Sekitar, sebagai narasumber pada materi ini adalah ketua pelaksana pengabdian Ibu Dr. Maryani, S.Pi, M.Si,
Kegiatan berjalan lancar diikuti oleh 15 peserta dari masing masing mitra, yang memiliki semangat dan motivasi yang tinggi untuk mendapatkan ilmu dan keterampilan tentang pemanfaatan tanaman obat sebagai swamedikasi. Meskipun ibu-ibu telah dikenalkan dengan berbagai jenis tanaman yang secara empiris dapat berkhasiat obat, namun kami juga menyampaikan bahwa untuk penyembuhan suatu penyakit maka diperlukan dosis pemakaian yang tepat. Selain itu, sekalipun banyak klaim penggunaan tanaman obat lebih aman dibandingkan penggunaan obat kimia, namun dijelaskan juga bahwa tidak sedikit tanaman obat juga dapat menimbulkan efek samping jika penggunaannya tidak tepat (Aziz dan Ghulamahdi, 2001).

Penggunaan bahan alam sebagai obat cenderung mengalami peningkatan dengan adanya isu

back tonature dan krisis berkepanjangan yang mengakibatkan turunnya daya beli masyarakat terhadap obat-obat modern yang relatif lebih mahal harganya. Obat bahan alam juga dianggap hampir tidak memiliki efek samping yang membahayakan. Pendapat itu belum tentu benar karena untuk mengetahui manfaat dan efek samping obat tersebut secara pasti perlu dilakukan penelitian dan uji praklinis dan uji klinis.

Dalam kegiatan ini, utamanya ibuibu dikenalkan terhadap jenis tanaman yang diantaranya sudah banyak dikenal sebagai tanaman hias namun ternyata juga dapat digunakan sebagai tanaman obat serta kelebihan dan kelemahan penggunaan bahan alam sebagai obat. Dan hal yang lebih penting adalah penjelasan lebih rinci tentang kandungan dan khasiat dari ketiga jenis tanaman obat yang telah dibagikan ke peserta pelatihan.

Untuk mengobati penyakit diperlukan waktu lama sehingga penggunaan obat alam lebih tepat, karena efek sampingnya relatif lebih kecil. Di samping keunggulannya, obat bahan alam juga memiliki beberapa kelemahan yang juga 
merupakan kendala dalam pengembangan obat tradisional antara lain efek farmakologisnya lemah, bahan baku belum terstandar dan bersifat higroskopis, belum dilakukan uji klinik dan mudah tercemar berbagai mikroorganisme (Zein, 2005).

Kunyit merupakan bahan yang sudah terkenal diberbagai negara, banyak digunakan sebagai ramuan jamu karena berkhasiat menyejukkan, membersihkan, menghilangkan gatal, dan menyembuhkan kesemutan. Rimpang tanaman kunyit itu juga bermanfaat sebagai analgetika, antiinflamasi, antioksidan, antimikroba, pencegah kanker, antitumor, dan menurunkan kadar lemak darah dan kolesterol, serta sebagai pembersih darah.

Selain kunyit, kencur dan jahe merah merupakan tanaman obat yang sering digunakan sebagai obat bahan alam. Umumnya, manfaat kencur sering digunakan sebagai obat sakit tenggorokan. Akan tetapi, selain bisa berkhasiat untuk sakit tenggorokan, kencur berfungsi sebagai obat sakit kembung, masuk angin, obat batuk, penambah nafsu makan, disentri, infeksi bakteri, sakit perut, ekspektoran, dll. Minyak atsiri yang dikandung kencur diklaim memiliki banyak senyawa bermanfaat. Senyawa ini berfungsi sebagai zat analgesic, yaitu zat yang memiliki kemampuan untuk mengurangi rasa sakit atau nyeri. Sedangkan jahe merah memiliki salah satu manfaat yang paling terkenal adalah untuk mengobati penyakit asma atau sesak nafas. Menurut pakar herbal, jahe merah memiliki khasiat menjaga fungsi saluran pernafasan. Kandungan zat bronki splasmolitika dalam jahe merah terbukti mambu membantu menyerap oksigen dengan baik dan mendukung paru-paru lebih sehat agar reaksi sel maskosit dan eosinofil tidak membahayakan tubuh penderita.

\section{Pelatihan Pembuatan Jamu Tradisional Beras Kencur dan Kunyit Asam}

Untuk meningkatkan kesehatan keluarga, upaya yang dapat dilakukan para ibu dalam keluarga adalah dengan mencegah kejadian sakit (Hariana, 2011). Oleh karena itu, dalam pelatihan ini ibu-ibu diajarkan praktek membuat ramuan jamu yang aman dikonsumsi sehari-hari yang berkhasiat untuk mencegah timbulnya sakit, yaitu jamu beras kencur dan kunyit asam. Kedua ramuan tersebut telah digunakan sejak ratusan tahun lalu di Bumi Pertiwi untuk meningkatkan kebugaran tubuh dan terbukti aman dikonsumsi setiap hari. Upaya mencegah sakit tentu lebih baik dibanding mengobati penyakit yang tentunya akan lebih banyak mengeluarkan biaya. Inilah pentingnya peran ibu dalam keluarga untuk memelihara kesehatan keluarga, sehingga melalui kegiatan ini, jika para ibu mempraktikkan dalam keluarganya diharapkan kejadian sakit dalam keluarga menjadi menurun.

Dalam rangkaian pelatihan pemanfaatan tanaman obat menjadi sediaan jamu untuk meningkatkan kesehatan dengan swamedikasi, terlebih dahulu peserta diberi penjelasan tentang cara pembuatan jamu dengan media presentasi. Untuk materi ini sebagai narasumber adalah praktisi yang berkecimpung di bidang pembuatan jamu tradisional disamping itu kegiatan sehariharinya para narasumber adalah berdagang jamu tradisional, pada pembuatan jamu beras kencur yang menjadi narasumber adalah Ibu Yayuk sedang narasumber pembuatan jamu kunyit asam adalah Ibu Soimah. Selain faktor sanitasi dan hygiene, juga disampaikan beberapa ramuan jamu yang dapat dibuat dalam skala rumah tangga.

Sebagian peserta yang sudah berusia lebih dari 50 tahun umumnya sudah tidak begitu asing, dengan pembuatan kunyit asam, beras kencur. Namun bagi peserta yang masih berusia di bawah 30 tahun umumnya belum begitu mengenal. Hal ini menunjukkan bahwa budaya minum jamu 
dan membuat jamu memang sudah mulai berkurang termasuk di Kelurahan Kalampangan. Oleh karena itu, edukasi ini sangat diperlukan untuk melestarikan pembuatan dan pengunaan jamu dalam meningkatkan kesehatan diri sendiri dan keluarga secara mandiri. Penggunaan jamu kunyit asam dan beras kencur utamanya adalah untuk mencegah timbulnya penyakit (Dalimartha, 2003; 2008). Praktik pembuatan jamu juga melibatkan ibu-ibu peserta pelatihan seperti terlihat pada gambar


Gambar 1. Kegiatan Praktek Pembuatan Jamu

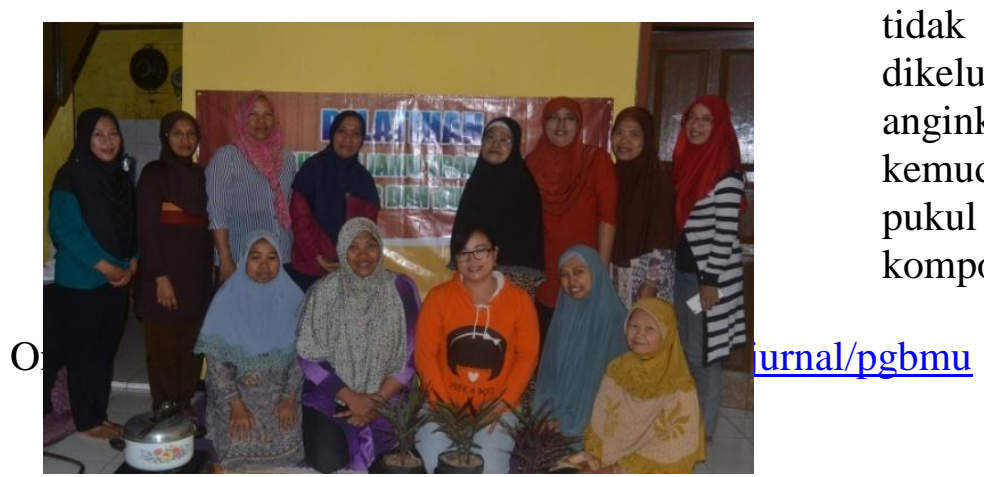

Gambar 2. Sebagian Peserta Pelatihan Berfoto Setelah Kegiatan Berakhir

Antusiasme ibu-ibu dalam praktik pembuatan ramuan jamu ini sangat tinggi ditunjukkan dengan pertanyaan-pertanyaan yang diajukan seputar teknis pembuatanya terutama komposisi bahan bakunya. Untuk memudahkan peserta dalam mempraktikannya di rumah, pada pelatihan ini juga kami bagikan materi presentasi yang memuat komposisi bahan-bahan untuk berbagai ramuan jamu yang secara tradisional digunakan untuk memelihara kesehatan keluarga seperti jamu beras kencur dan jamu kunyit asam.

\section{Pelatihan Pembuatan Kompos Organik dari Limbah Rumah Tangga}

Pada pelatihan pembuatan kompos organik, narasumber Ibu Rosdiana sebagai anggota tim pelaksana pengabdian. Pelatihan pembuatan kompos buatan ini dilakukan dengan media yang sangat sederhana untuk memanfaatkan sampah limbah organik menjadi bahan pupuk yang diharapkan dapat menyuburkan budi daya tanaman obat. Media yang digunakan adalah sampah organik seperti sisa makanan/potongan sayuran, kulit buah yang telah dirajang. Peserta dengan ceria dan tidak merasa jijik memilah-milah sampah limbah rumah tangga disiapkan untuk dirajang kemudian direndam dengan air bekas cucian beras atau air kelapa, dan sebagai bahan untuk fermentasinya digunakan gula merah.

Kegiatan berikutnya adalah tinggal menunggu hasil kompos yang diperoleh, yakni setelah proses pengkomposan selama 6 7 hari. Hasil yang diperoleh berupa pupuk cair dan kompos padat yang sudah tidak berbau Kompos padat yang baru dikeluarkan didinginkan dan dianginanginkan hingga nampak kering. Baru kemudian dihaluskan dengan cara dipukulpukul dan diayak sehingga diperoleh kompos padat siap dikemas atau siap 
dipakai. Melalui pelatihan ini diharapkan ada peningkatan keterampilan ibu-ibu PKK yang secara tidak langsung berdampak pada kesuburan tanaman obatnya.

Terjadi kerjasama antara masyarakat dengan tim pelaksana secara harmonis dan komunikatif, ada kesesuaian waktu pelaksanaan dengan kegiatan masyarakat, menumbuhkan kemandirian masyarakat, serta hasil kegiatan pelatihan ini sangat diharapkan untuk ditindaklanjuti masyarakat setempat.

\section{Monitoring dan Evaluasi Hasil Kegiatan}

Berdasarkan hasil evaluasi dari kegiatan yang telah dilakukan melalui kunjungan dan wawancara dengan peserta dua bulan setelah pelatihan, diperoleh informasi bahwa cara pembuatan jamu tersebut sekali-sekali telah mereka praktikan dalam keluarga masing-masing, bahkan beberapa orang dari peserta pelatihan beberapa kali telah memberikan praktik kepada ibu-ibu di wilayahnya yang tidak mengikuti pelatihan.

Berkaitan dengan penanaman tanaman obat, hasil kunjungan, dan wawancara, dapat diketahui bahwa bibit tanaman yang diberikan masih terpelihara dengan baik. Sebagian peserta yang tidak memiliki lahan, bibit tanaman ditanam di lahan yang digarap dan dipelihara secara bersama-sama. Selain itu, budi daya tanaman obat juga dapat dilakukan dalam media yang ditempatkan dalam wadah bekas dan talang air, seperti terlihat pada Gambar 3.

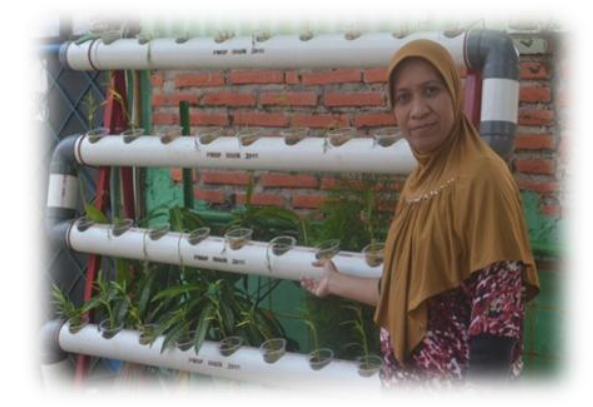

Gambar 3. Budidaya Tanaman Obar Pada Wadah Bekas Talang Air

Dari uraian diatas, tampak bahwa kegiatan ini telah memberikan dampak pada ibu-ibu PKK, yaitu meningkatnya pengetahuan ibu-ibu PKK akan jenis-jenis tanaman yang berkhasiat sebagai obat yang dapat digunakan untuk swamedikasi bagi keluarganya. Namun demikian, karena menjaga kesehatan atau mencegah sakit tentu lebih penting, maka ramuan tradisional yang dapat dibuat sehari-hari adalah beras kencur dan kunyit asam. Adapun dampak terjadinya peningkatan kesehatan atau menurunnya angka sakit dengan adanya kegiatan ini belum dapat diketahui karena data dari puskesmas belum dapat kami peroleh, namun budaya minum jamu beras kencur dan kunyit asem sebagai upaya swamedikasi semakin meningkat. Selain itu, praktik pembuatan jamu juga telah disebarkan kepada warga lain oleh peserta pelatihan (ibu-ibu kader PKK) pada warga yang tidak mengikuti pelatihan, yaitu pada kegiatan rutin pertemuan ibu-ibu (arisan bulanan) di setiap RT. Melalui komunikasi yang berjalan baik antara peneliti dengan mitra, diharapkan budi daya toga dapat terus berlanjut dan menciptakan lingkungan yang asri di wilayah Kelurahan Kalampangan.

\section{KESIMPULAN}

Kegiatan pemberdayaan yang melibatkan kelompok ibu-ibu PKK Kelurahan Kalampangan Kecamatan Sabangau Kota Palangka Raya telah berjalan dengan baik, meliputi kegiatan pelatihan pengenalan tanaman obat, praktik pengolahan tanaman obat menjadi sediaan minuman cair dan pembuatan kompos organik.

Melalui kegiatan ini telah terjadi peningkatan pengetahuan dan keterampilan warga terhadap jenis-jenis tanaman yang berkhasiat obat. Selain itu, hasil dari kegiatan ini juga meningkatkan konsumsi ramuan beras kencur dan kunyit asam dalam 
keluarga sebagai bentuk swamedikasi meningkatkan kebugaran dan mencegah sakit. Juga meningkatnya pengetahuan dan keterampilan warga terhadap pembuatan kompos organik sehingga limbah rumah tangga dapat dimanfaatkan dan dikelola dengan baik dan hasil tambahan lainnya adalah dihasilkannya pupuk organik produksi warga setempat sehingga dapat dimanfaatkan untuk kesuburan tanaman yang dipelihara.

Perlu dilakukan komunikasi yang berkelanjutan dengan mitra agar kegiatan ini dapat terus berjalan, budi daya tanaman obat terus berkembang dan menyebar untuk warga lain disekitarnya, sehingga dapat meningkatkan penghasilan warga dan hal yang penting adalah pelaksanaan swamedikasi dengan tanaman obat sehingga berdampak pada peningkatan kesehatan tubuh warga.

\section{REFERENSI}

Aziz SA, Ghulamahdi M. 2001. Standarisasi teknologi penyediaan bahan tanaman obat. Bogor (ID): Institut Pertanian Bogor.

Dalimartha S. 2003. Atlas Tumbuhan Obat Indonesia Jilid 3. Jakarta (ID): Puspa Swara.

Dalimartha S. 2008. 1001 Resep herbal. Jakarta (ID): Penebar Swadaya.

Dalimartha S. 2008. Atlas Tumbuhan Obat Indonesia Jilid 5. Jakarta (ID): Puspa Swara.

Hariana, A. 2011. Tumbuhan Obat dan Khasiatnya. Penebar Swadaya. Jakarta.

Pusat Studi Biofarmaka. 2003. Panduan Pelatihan Tanaman Obat Tradisional (Swamedikasi): Pengobatan Penyakit
Diabetes Mellitus. Bogor (ID): Pusat studi Biofarmaka, Lembaga Penelitian dan Pengabdian kepada Masyarakat, Institut Pertanian Bogor.

Winkanda SP. 2013. Sehat dengan herbal tanpa Dokter. Yogyakarta (ID): Citra Media.

Zein, U. 2005. Pemanfaatan Tumbuhan Obat dalam Upaya Meningkatkan Pemeliharaan Kesehatan. USU Repository. Medan. 